Fr. Matthew Janeczko, OFM Cap.

Boston College

School of Theology and Ministry

\title{
Augustine on Sacrifice: A Synthesis
}

\begin{abstract}
This essay investigates the manner in which Augustine writes about the related topics of sacrifice, priesthood, and mediation. Drawing upon the Confessions, The Trinity, and the City of God, as well as relevant secondary literature, it concludes that an understanding of Augustine's views regarding these topics allows for a broader comprehension of the proper ends of Christian life: true acts of charity and worship.
\end{abstract}

\section{Introduction}

This essay seeks to engage several texts of Augustine of Hippo in which he attempts to define and describe the role of Christ as priest and victim, as well as his broader understanding of Christian sacrifice vis-à-vis the Eucharist. In order to achieve this, I will trace the development of Augustine's theology of sacrifice through the Confessions, The Trinity, and the City of God. It is my hope that this synthesis of Augustine's theology of sacrifice will illuminate the overarching meaning of several key themes to which he returned throughout his life. In the final analysis, I argue that a proper understanding of Augustine's theology of sacrifice allows more accurate comprehension of Augustine's writings as a whole and allow readers to better grasp the nature of the Eucharist as a sacrifice.

The matter of sacrifice is present through the Confessions, The Trinity, and the City of God in ways both implicit and explicit. For the sake of clarity and brevity, I have decided to focus on the passages where Augustine treats sacrifice directly and at length. As such, I will first examine the relevant parts of Books IX and X of the Confessions. Here, I will attempt to build upon John Cavadini's "Eucharistic Exegesis" of Book IX, arguing that it is actually in Book X, wherein Augustine references his own priesthood, that the groundwork for an Augustinian 
synthesis of sacrifice is first developed. ${ }^{1}$ While Augustine does not specifically employ the term "sacrifice" in Book X, he does, in summarizing his conversion experience(s), articulate the importance of Christ's mediation as both priest and victim. From there, I will turn to Book IV of The Trinity. Here Augustine describes the connection between Christ's sacrifice and priesthood. Augustine thus connects the actions of Christ with the communal action of the Eucharist. Finally, I will treat Book X of the City of God in order to note where Augustine provides his most extensive and developed treatment of sacrifice. The locus of this examination will be X.6, in which Augustine discusses the importance of sacrifice made to God, humanity's inability to provide a proper sacrifice, and, as a consequence of this, the importance of Christ's sacrifice in the entire soteriological project. This exegesis builds to what Gerald Bonner has called "the finest short statement of Augustine's thought in the whole of his writings" on this matter, in X.20, at which point the Augustinian synthesis of sacrifice reaches its culmination in all its ecclesiological, sacramental, and Christological significance. ${ }^{2}$ It should be noted at the outset that I will engage neither Augustine's liturgical homilies nor his letters that treat elements of sacrifice: to do so would greatly expand the length beyond the desired length.

This paper concludes with some points of continuity and development of Augustine's treatment of sacrifice. It ought to become clear at that point that Augustine viewed sacrifice as a necessary process in the larger project of ascent to God; moreover, for Augustine, Christ played a constitutive and eternal role as priest, mediator, and sacrifice in this same process. ${ }^{3}$ This essay will also note that Augustine (correctly) portrayed Christ as more than an ethical example of how one ought to live a Christian life, but rather claimed that in the Eucharist Christians re-presented

\footnotetext{
${ }^{1}$ John C. Cavadini, "Eucharistic Exegesis in Augustine's Confessions," Augustinian Studies 41:1. (2010) 87-108.

${ }^{2}$ Gerald Bonner, "The Doctrine of Sacrifice: Augustine and the Latin Patristic Tradition," Sacrifice and Redemption: Durham Essays in Theology, ed. S.W. Sykes, (Cambridge, UK: Cambridge, University Press, 1991) 107.

${ }^{3}$ John Cavadini, "Eucharistic Exegesis," 98.
} 
and appropriated the locus of Christian existence itself: adoration and unification with God. ${ }^{4}$ In order to organize these thoughts, I will broaden heuristic categories provided by John Cavadini in his treatment of the Eucharist in the Confessions to consider how Augustine articulated his understanding of sacrifice, priesthood, and mediation in The Trinity and the City of God as well.

\section{The Confessions}

The final chapters of Book X of the Confessions attempt to shed light upon the manner in which Augustine viewed Christ's role not only in his own conversion, but also in the broader manner in which The Trinity attempted to call humanity into relationship. Augustine asks in X.67, "Whom could I find to reconcile me to you?"5 Responding to this question, he immediately discards three options: seeking the assistance of angels, reconciling God to himself through his own efforts, and the use of spiritual mediums that were all, in reality, manifestations of the devil. ${ }^{6}$ After rejecting these three options, Augustine concludes that what was really needed was, "a mediator to stand between God and men who should be in one respect like God, in another kin to human beings, for if he were manlike in both regards he would be far from God, but if Godlike in both, far from us; and then he would be no mediator." "Through this description, Augustine sets the stage for his argument that Christ exists as the perfect mediator: fully human and divine, Christ is the only one suited to bridge the gap that exists between God and humanity because of $\sin$. Augustine continues his description of the role played by "the man Christ Jesus," writing, “This Mediator... appeared to stand between moral sinners and the God

\footnotetext{
${ }^{4}$ Earl Muller, "The Priesthood of Christ in Book IV of the De trinitate," Augustine: Presbyter Factus Sum, ed. Joseph Linehard, (New York, NY: Peter Lang, 1993) 140.

${ }^{5}$ Augustine, Confessions, trans. Maria Bouldling, (New York: Random House, 1997) X.67.

${ }^{6}$ Ibid.

7 Ibid.
} 
who is immortal and just; like us he was mortal, but like God he was just." ${ }^{8}$ That Christ is the perfect figure to mediate the relationship between humanity and God is a claim to which Augustine often returns. ${ }^{9}$ The use of the term mediator assisted Augustine, argues Brian Daley, in crafting a doctrine of Christ that balanced his deep belief in the Incarnation with a NeoPlatonist worldview resting on the transcendence of God. ${ }^{10}$ Moreover, Robert Daly notes that Augustine's view of the role of Christ as mediator is particularly worldly: the actions of Christ during his human life make manifest his eternal mediation. ${ }^{11}$ That Augustine speaks of mediation in this way is significant because it paves the way for the continued meditation of Christ in and through the Eucharist - again, a process that takes place in this world, yet links humanity to God's transcendence through Christ.

As Augustine continues his explanation of Christ as mediator, he notes that it is not in Christ's "nature as the Word" that humanity is joined to Christ. ${ }^{12}$ Rather, "Only in virtue of his humanity is he the Mediator." ${ }^{13}$ Augustine then shifts to a more detailed examination of Jesus' mediation. This line of inquiry builds upon Augustine's previous insights regarding what Jesus is mediating (the relationship between God and humanity) and how he mediates (as human, not as the Word per se). Augustine names Christ as freely given by the Father, and that, as a consequence of Christ's free acceptance of this death, his status as the only person possessing "the power to lay down his life and the power to retrieve it." ${ }^{\prime 4}$ Augustine describes this process with more precision when he notes: "For our sake he stood to you as both victor and victim, and

\footnotetext{
${ }^{8}$ Ibid., X.68.

${ }^{9}$ Brian Daley, “A Humble Mediator: The Distinctive Elements in Saint Augustine's Christology," Word and Spirit 9 (1987): $101 ; 105-108$.

${ }^{10}$ Ibid., 106.

${ }^{11}$ Robert Daly, "Sacrifice in Origen and Augustine," Studia Patristica, ed. Elizabeth Livingstone, (Leuven: Peters Press, 1989)152.

${ }^{12}$ Augustine, Confessions, X.68

13 Ibid.

${ }^{14}$ Ibid.
} 
victor because victim." 15 He then builds upon the terms of "victor" and "victim," writing, "for us he stood to you as priest and sacrifice, and priest because sacrifice." ${ }^{\prime 16}$ Once again, Augustine attempts to make the point that Christ's identity as mediator is unique because he is both the subject offering the sacrifice, as well as the one sacrificed. Because of this, Christ links the human and divine in a manner that brings God close to humanity in his divinity, and humanity near to God in its mortality. ${ }^{17}$

Augustine turns to his need for a redeemer and his own role as priest in re-presenting the mediation offered by Christ through his life at the conclusion of Book X. Augustine acknowledges that he is "filled with terror by [his] sins," yet at the same time knows that he has been "redeemed with his [Christ's] blood."18 This is not merely a passive reception, however, because Augustine recognizes his own participation in both his "ransom" and that of others. $\mathrm{He}$ writes, "I eat it [the ransom], I drink it, I dispense it to others, and as a poor man I long to be filled with it among those who are fed and feasted." ${ }^{\prime 19}$ Augustine refers here to his own actions as priest because he acted in such a way as to re-present the sacrifice of Christ. One ought to note that by the time he wrote City of God, Augustine will have broadened his notion of sacrifice as it pertains to Christian activity in the world. ${ }^{20}$ Yet, even now in the Confessions, Augustine recognizes that the sinful world is reconciled by the actions of Christ's mediation on the cross; moreover, this same sacrifice is both remembered and made manifest in the participation of Christians in the Eucharist. As a priest, Augustine recognized that he both bore the responsibility of sharing this sacrifice with others and remained in need of its benefits.

\footnotetext{
${ }^{15}$ X.69.

${ }^{16} \mathrm{Ibid}$.

${ }^{17}$ X.68.

${ }^{18}$ X.70.

${ }^{19}$ Ibid.

${ }^{20}$ Robert Daly, "Sacrifice in Origen and Augustine," 153.
} 
John Cavadini views Book X of the Confessions, specifically its Eucharistic themes, as proceeding from Augustine's comments in Book IX. Cavadini does not, however, link his work on Book IX to the latter portions of Book X as has been done here. This is, I would argue, an oversight on the part of Cavadini. Nevertheless, he does provide some valuable context for a deeper understanding of the way in which Augustine writes about the Eucharist in Book X. Cavadini draws upon Monica's request to be remembered at the altar after her death as proscriptive for understanding Augustine's treatment of the Eucharist in Book IX. ${ }^{21}$ Augustine, Cavadini reasons, understands the Eucharist as existing at the intersection of memory and hope, that is to say, history and eschatology. ${ }^{22}$ Perhaps even more important to our task, Cavadini claims that Christ "is further identified as the very one whose mercy is measured by the price he paid for it, of which the Eucharist is the sacrament." ${ }^{, 3}$ This is an important point to understand: according to Cavadini, the Eucharist is itself the re-presentation of the saving mediation offered by Christ in his death. At the same time, it seems peculiar that Cavadini avoids the language of mediation offered by Augustine himself at the conclusion of Book X. Nevertheless, Cavadini's treatment of the Eucharist in the Confessions allows him to conclude that the work itself is actually an act of remembrance: Eucharist in the most basic sense. ${ }^{24}$ The emphasis placed by Cavadini upon the idea of remembrance, and more specifically in its Eucharistic manifestations, is well founded. This allows a fuller appropriation of the connection Augustine saw between the sacrificial nature of Christ's death and its re-presentation in the Eucharist as described by the Confessions in both Books IX and X that would have otherwise been possible.

\footnotetext{
${ }^{21}$ Augustine, Confessions, IX.27.

${ }^{22}$ Cavadini, "Eucharistic Exegesis," 89.

${ }^{23}$ Ibid., 93.

${ }^{24}$ Ibid., 103.
} 
The themes highlighted above in my analysis of the Confessions include Augustine's understanding of Christ's role as mediator and the re-presentation of his saving mediation in the sacrament of the Eucharist. I now turn my attention to The Trinity, wherein Augustine will continue to develop his synthesis of Christ's place as both priest and victim with greater detail.

\section{The Trinity}

This section examines specific portions of Book IV of The Trinity in an effort to highlight the priesthood of Christ that originates in his sacrifice on the cross. By addressing certain elements of the second and third chapters of Book IV, I will demonstrate how The Trinity moves beyond the outline of Christ's role as mediating sacrifice described by Augustine in the Confessions. What is more, the union of believers in Christ, through the Eucharist, is, for Augustine, the appropriate way to recall Christ's sacrifice because it manifests his role as both victim and priest. ${ }^{25}$ If the above analysis of the Confessions noted Christ's role as priest, victim, and mediator, and my later analysis of the City of God will describe Augustine's broader views regarding the proper sacrifice offered by Christians in response to Christ's own sacrifice, then The Trinity presents itself as the middle term: Christ's actions as priest and victim attends to the need for humans to be reconciled to God, as well as to each other. ${ }^{26}$ Indeed, for Augustine, there are two necessary ways in which Christ brings unity, bridging the gap between the Creator and the created, as well as among the created themselves. ${ }^{27}$ Both Gerald Bonner and Earl Muller describe how Augustine continued to develop the theological notion of sacrifice and mediation in such a way as to make its Eucharistic underpinnings more explicit, and, in doing so, draw out the manner in which Augustine develops the intimate link between the sacrifice and priesthood of

\footnotetext{
${ }^{25}$ Gerald Bonner, "The Doctrine of Sacrifice," 107.

${ }^{26}$ Earl Muller, "The Priesthood of Christ," 143.

${ }^{27}$ Augustine, The Trinity, trans. Edmund Hill, (Hyde Park, NY: New City Press, 2010) IV.ii,9.
} 
Christ. Augustine thus positions Christ as a more than a "mediating reality as Platonism conceived this. ${ }^{28}$ Rather, in Christ, Augustine found the means by which Christians could themselves be made acceptable to God: by making Christ's sacrifice their own through the Eucharist. An entire examination of The Trinity and its appropriation of Christ's sacrifice and mediation is not possible in my limited space here, yet it is my hope to demonstrate the points of coherence with the Confessions, as well as point towards Augustine's treatment of sacrifice in City of God X.

In Book IV,ii,11, Augustine describes Christ as "this sacrament, this sacrifice, this high priest, this God. ${ }^{29}$ These terms connect back to the previously examined material in the Confessions: Christ himself is the sacrifice offered as well as the priest who offers it. At the same time, Christ remains God, the receiver of the sacrifice, as well as the sacrament, that is the symbol that makes the sacrifice manifest. This four-part description offered by Augustine remains operative throughout The Trinity. Augustine recognizes that the reality of Christ's coming and his sacrifice makes believers "one in the just one [Christ]." ${ }^{30}$ Once again, Augustine emphasizes that Christ is more than an example: his role is one of reconciliation to the Father as well. He concludes, "that thus fully reconciled to God by him the mediator, we may be able to cling to the one, enjoy the one, and remain for ever one." ${ }^{31}$ Immediately previous to this, however, Augustine also refers to Christ as "the head." 32 The relationship should now be clear: not only does Christ reconcile sinful humanity to the Father through his mediation as priest and sacrifice, he also enacts reconciliation among humans themselves under his one headship. The divine-human reconciliation is achieved through Christ's sacrifice; the human-human healing

\footnotetext{
${ }^{28}$ Earl Muller, "The Priesthood of Christ,"135.

${ }^{29}$ The Trinity, IV, ii, 11.

${ }^{30}$ Ibid.

${ }^{31}$ Ibid.

${ }^{32}$ Ibid.
} 
takes place in the re-presentation of Christ's sacrifice at the common altar. Such a re-positioning of humans in relationship to each other is remembered - no, even more so, enacted - through the celebration of the Eucharist. ${ }^{33}$ The priesthood of Christ, then, is, according to Earl Muller, more than an "ontological mediation." ${ }^{, 34}$ Christ's priesthood not only links sinful humanity with God, but also humans with one another.

Having parsed the effects of Christ's sacrifice, Augustine next recalls an important Christological theme, noting that the Son of God exists both in equality with the Father, as well as the mediator between the Father and humanity due to his incarnation. ${ }^{35}$ Augustine articulates just why humanity requires a mediator that is both God and human - that is to say, priest and victim. Humans themselves, Augustine notes, are "split as they are from each other by clashing wills and desires, and the uncleanness of their sins," and therefore require a mediator possessing their same nature, yet surpassing human righteousness. ${ }^{36}$ Indeed, for Augustine, the true import of the Christ event is that he exists as both the mediator of God's word and the Word itself. Christ is thus the unique and enduring mediator: no sacrifice, no priest, nor any victim may compare with his. Christ may intercede with God while remaining God. Augustine contrasts Christ's actions with those of the "mediator to death," that is, Satan. ${ }^{37}$ The paths of mediation taken by Christ and Satan both depart from the same nexus, that is, sacrifice, yet possess diametrically opposed ends. Whereas both Christ and Satan are able to offer their "single death," the latter has no resurrection to offer. ${ }^{38}$ What is more, since Satan possesses no resurrection, he cannot offer a "sacrament," that is, a symbol of resurrection, to those who participate in his

\footnotetext{
${ }^{33}$ Earl Muller, "The Priesthood of Christ,"139.

${ }^{34}$ Ibid., 136.

${ }^{35}$ The Trinity, IV, ii, 9.

${ }^{36}$ Ibid.

${ }^{37}$ Ibid., IV, iii, 17.

${ }^{38}$ Ibid.
} 
sacrifice. ${ }^{39}$ Gerald Bonner seizes upon what he calls Christ's ability to offer "self-oblation." This self-gift has the effect of taking away "whatever there was of guilt, for which the principalities and powers had a right to hold us bound to payment of the penalty. ${ }^{, 41}$ Bonner notes that, in Augustine's eyes, the gift of Christ on the cross is "the one, true, perfect and sufficient sacrifice, oblation and satisfaction, upon which all others depend." ${ }^{, 2}$ This sacrifice, then, is made perfect not only by what is offered, but also by the person offering it.

Augustine articulates the efficacy of Christ's work both in terms of his activity as mediating sacrifice and priest. He then attempts to develop the effects of such a sacrifice in humanity's relationship with God. Of course, there is also the element of reconciliation to which I previously alluded. Yet, it is even more than that: there is a "unitive and transformative" element to Christ's death. ${ }^{43}$ Muller explains this matter by noting the intricate connection between the mediation and priesthood of Christ. ${ }^{44}$ The consequence of this connection draws out an element that will be more fully explained in City of God: "all worship has at least two purposes - adoration of God and unification with God." ${ }^{45}$ What Muller is attempting to do here (correctly, in my opinion) is to link the priestly action and sacrificial offering of Christ with the subsequent worship of Christians. More than just expiation, the mediation of Christ, made present in the Eucharist, allows Christians to offer the same sacrifice as Christ to the Father through Christ. And the offering is, of course, Christ himself. All of this takes place in the Eucharist. In other words, since Christians are purified through the sacrificial offering of Christ,

\footnotetext{
${ }^{39}$ Ibid.

${ }^{40}$ Gerald Bonner, "Doctrine of Sacrifice," 105-6

${ }^{41}$ The Trinity, IV, iii, 17.

42 Gerald Bonner, "Doctrine of Sacrifice," 105.

${ }^{43}$ Earl Muller, "The Priesthood of Christ," 147, n. 28.

${ }^{44}$ Ibid., 140 .

45 Ibid.
} 
they are subsequently able to participate in the same offering, re-presented in the "sacrament of the altar." 46

To further clarify matters, one ought to recall the four elements of sacrifice described by Augustine himself:

Now there are four things to be considered in every sacrifice: whom it is offered to, whom it is offered by, what it is that is offered, and whom it is offered for. And this one true mediator, in reconciling us to God by his sacrifice of peace, would remain one with him to whom he offered it, and make in himself those who from he offered it, and be himself who offered it one and the same as what he offered. ${ }^{47}$

The manner in which Augustine writes about the subject and object of Christ's sacrifice is given further amplification by Robert Daly, who, in considering the matter, views Augustine as “[seeing] Christ's sacrificial redemptive work as having been completed by Christ in this world. [italics his]"48 The consequence of the "worldliness" of Christ's sacrifice is to make clear the Christian's ability to participate in this same sacrifice. The relationship between Christ's sacrifice on the cross and its re-presentation on the altar makes itself known in a more explicit manner in The Trinity. Yet, the fullness of the connection between the sacrifice of the altar and the sacrifice on the cross will not reach its full explanation until City of God.

\section{The City of God}

In order to conclude my synthesis of sacrifice in the writings of Augustine, I will now focus on certain portions of Book X of the City of God. In Book X, Augustine not only connects the sacrifice of Christians as making up the one Body of Christ, but also links this same sacrifice with the Eucharist. ${ }^{49}$ Broadly stated, Christ exists as perfect priest and sacrifice; Christians are

\footnotetext{
${ }^{46}$ Ibid., 144.

${ }^{47}$ The Trinity, IV.iii, 19

${ }^{48}$ Robert Daly, "Sacrifice in Origen and Augustine," 152.

${ }^{49}$ Ibid., 152.
} 
saved by this sacrifice, and then they re-present the sacrifice both in the Eucharist and their own acts of compassion.

In City of God X.5, Augustine explains an apparent paradox present in Sacred Scripture: God appears to both desire and not desire sacrifice. Augustine's subsequent analysis takes under consideration three different versions of "sacrifice" that his readers would have intuited: (1) pagan, physical sacrifices; (2) sacrifices prescribed by Judaism; and (3) "the self-offering of Christ on Calvary, the great sacrifice. ${ }^{, 50}$ To these three, one may add a fourth, albeit one related to Christ's sacrifice: "the Christian eucharist, which had long been regarded as re-presenting or reactualizing the sacrifice of the cross. ${ }^{51}$ These distinctions are important to keep in mind when Augustine suggests that God does not desire physical sacrifices as such, but rather those that come from conversion and love of neighbor. Augustine writes that God does not necessarily not desire sacrifice, but rather finds fault with the disposition of those who believe that God will be pleased by the sacrifices of humans themselves - as if their very offering may please God. The appropriateness of the sacrifice, therefore, originates in the disposition and conduct of the one offering the sacrifice, over and above the material offered. Thus, God does indeed desire sacrifices: but only those that originate as acts of charity. Augustine explains: "Hence the meaning of the text, 'I desire mercy rather than sacrifice,' is simply that one sacrifice is preferred to another; for what is generally called sacrifice is really a sign of the true sacrifice." ${ }^{52}$ This explanation of the sacrifice desired by God leads to Augustine's next task - and a pivotal one for anyone wishing to understand the way he understands sacrifice, mediation, priesthood and the Eucharist.

\footnotetext{
${ }^{50}$ Gerald Bonner, "The Doctrine of Sacrifice,"104.

${ }^{51}$ Ibid.

${ }^{52}$ Augustine, City of God, trans. Henry Bettenson, (London: Penguin Books, 2003). X,5.
} 
In order to further clarify what he means by proper sacrifice, Augustine turns to Romans 12. He quotes verse one in full, and then explains that since the body is subordinate to the soul, the offering of the soul as a sacrifice possesses more meaning to God than would a body. Augustine asks, "how much more does the soul itself become a sacrifice when it is offered to God, so that it may be kindled by the fire of love and may lose the 'form' of worldly desire, and may be 're-formed' by submission to God ... thus becoming acceptable to God because of what it has received form his beauty." compassion, whether towards ourselves or towards our neighbors, when they are directed toward God. ${ }^{, 54}$ These acts of compassion, however, are not offered in and of themselves; rather, Augustine explains that "the whole redeemed community ... is offered to God as a universal sacrifice through the great Priest who offered himself in his suffering for us - that we might be body of so great a head - under 'the form of a servant." sacrifice are precisely Christian if and when they originate in the sacrifice of Christ. It is in and through Christ's sacrifice that acts of compassion made by Christians are directed toward God. Christ's sacrifice has the additional function of bringing Christians as a body under his priestly action. This is significant because Christians become members of the Body of Christ through Christ's mediation. Augustine explains the role of Christ as priest thusly: "For it was this form he offered, and in this form he was offered, because it is under this form that he is the Mediator, in this form he is the Priest, in this form he is the Sacrifice. ${ }^{, 56}$ Christians are able to shape their lives according to the model of Christ and not to that of the world because they are the recipients and participants in Christ's sacrifice. This reception and participation finds its locus in the

\footnotetext{
${ }^{53}$ Augustine, City of God, X,6.

${ }^{54}$ Ibid.

${ }^{55}$ Ibid.

${ }^{56}$ Ibid.
} 
worship of God and subsequent actions of compassion (=sacrifice). Augustine does not cut a sharp distinction between the sacrifice and worship and sacrifice of compassion, likely because he sees them as both actively uniting the Christian with his or her neighbor and God. ${ }^{57}$

Augustine concludes X.6 by making explicit the connections between membership in the Body of Christ, reception of the Eucharist, and the participation of the Christian people in Christ's own priesthood: "This is the sacrifice which the Church continually celebrates in the sacrament of the altar, a sacrament well-known to the faithful where it is shown to the Church that she herself is offered in the offering which she presents to God.. ${ }^{58}$ These final lines of X.6 indicate that Augustine considered the Body of Christ in multivalent terms: not only was the Body of Christ sacrificed on the cross, but so too does the Body of Christ - the Church continue to re-present the sacrifice of Christ on the altar in the Eucharist. What is more, since the Body of Christ (Church) has Christ himself as its head, the Church offers itself as a continual sacrifice through acts of compassion and worship in imitation of the original sacrifice of Christ on the cross. The overarching significance of this Augustinian insight is clarified by Robert Daly, who notes in Augustine's City of God a real interest in the actions of Christians in the world. This recognition roots itself both in the importance of the communal liturgy (Eucharist) as well as in the way in which Christians participate in and bring to completion "Christ's work of sacrificial redemption" as pilgrims in the earthy city. ${ }^{59}$

Later in Book X, Augustine addresses the reason why Christians offer visible sacrifices to a God who is invisible. He notes that some would argue that since the invisible God is great, invisible sacrifices are the only appropriate ones to make. Augustine answers these questioners by noting that "visible sacrifices are symbols of the invisible offerings, just as spoken words are

\footnotetext{
${ }^{57}$ Earl Muller, "The Priesthood of Christ," 140.

${ }^{58}$ Ibid.

${ }^{59}$ Robert Daly, "Sacrifice in Origen and Augustine," 152-3.
} 
the symbols of things. ${ }^{\circ 60}$ Augustine thus draws out an analogy of language used in prayer: words themselves are not prayer, but rather they are the outward signs of the pray-ers inner disposition. ${ }^{61}$ Moreover, these sacrifices of praise (and charity) are to be offered solely to God because he is the only one deserving such praise; as such, invisible praise, manifested in the form of words, makes the human him- or herself a visible sign of the invisible sacrifice taking place in the heart. Augustine continues by insisting that this type of sacrifice - the ones human make to God - cannot take place when the praise of humanity is directed toward anyone but God. Here is the importance of the sacrifice of Christ, since he is the only one able to make a perfect sacrifice of his life to God. Humans may thus properly make sacrifice while participating in the sacramental (symbolic) sacrifice of Christ, that is to say, the Eucharist.

A brief examination of X.20 will conclude my treatment of sacrifice in the City of God. This compliments the earlier exposition of Augustine's thought because it points out the role of mediation played by Christ between God and humanity in an explicit way. Augustine cites Phil. 2:6, because since "[Christ] took the form of a servant," he was able to mediate between God and humanity. ${ }^{62}$ This mediation allowed him to both serve as the sacrifice itself, as well as to accept the sacrifice made. Equally as important to this realization is the additional supposition offered by Augustine that Christ himself chose to offer himself as the sacrifice since this was commensurate with the role of a servant. Because of this, "[Christ] is both the priest, himself making the offering, and the oblation." ${ }^{63}$ Augustine continues, "This is the reality, and the intended the daily sacrifice of the Church to be the sacramental symbol for this; for the Church,

\footnotetext{
${ }^{60}$ Augustine, City of God, X.19.

${ }^{61}$ Ibid.

${ }^{62}$ Ibid., X.20

${ }^{63}$ Ibid.
} 
being the body of which he is the head, learns to offer itself through him.."64 One may see here many of the themes previously mentioned by Augustine in the Confessions, The Trinity, and earlier in the City of God. Christ prepares the sacrifice as priest, and offers his own self as victim; this sacrifice becomes the model by which all other Christian sacrifices take their cues, whether they be sacrifices of praise (worship) or charity (action). Christ's sacrifice is expiatory, as the perfect sacrifice, pedagogical, since it teaches the Church correct sacrifice, and exemplary, since the Church as Body is obliged to imitate its head, Christ.

Before concluding this section, I should note what may be a helpful analysis provided by John O'Grady regarding Augustine's understanding of sacrifice as located within the larger biblical tradition. O'Grady places sacrifice at the core of biblical religion beginning with the sacrificial offering of the Old Testament. Sacrifice in the New Testament, O'Grady continues, finds its main expression in the "breaking of the bread." ${ }^{65}$ O'Grady argues that Augustine bases his understanding of sacrifice within this same theological tradition. He enumerates three particular elements: (1) the "end of the sacrifice" as "union with God"; (2) the sacrifice of the Eucharist as manifesting the invisible, internal sacrifice; and (3) "the sacrifice of Christians in Christ." ${ }^{, 66}$ O'Grady then emphasizes what was first mentioned above: Augustine relies upon the beginning of Romans 12 to help him explain the nature of the sacrifice that Christians are expected to make. The key element of Augustine's understanding of sacrifice is the matter of whether it is "true" or not. In other words, the main question about the efficacy of a sacrifice is denoted by whether it "unites us in a holy communion with God." ${ }^{167}$ In the final analysis, O'Grady appropriates Augustine's description of true sacrifice, insofar as it is related to the

\footnotetext{
${ }^{64}$ Ibid.

${ }^{65}$ John O'Grady, "Priesthood and Sacrifice in the City of God," Augustinia, 21(1971) 29.

${ }^{66}$ Ibid., 30.

${ }^{67}$ Ibid., quoting City of God, X.6
} 
moral trajectory of the Christian. This sacrifice - an invisible disposition - thus requires signs of visible sacrifice, namely those of charity and participation in the sacrament of the altar. The visibility of these signs are not required in order to achieve devotion to God per se, but rather are the ways in which Christians demonstrate their desire to achieve the only proper end of life: eternity with God.

\section{Conclusions}

In his treatment of the Eucharist in the Confessions, John Cavadini focuses, as mentioned in the first section of this essay, primarily upon Book IX, that is to say, the time in Augustine's narrative immediately previous to and after Monica's death. Cavadini elucidates several Eucharistic themes from his exegesis, but stops short of a full appropriation of this topic by not linking it to the end of Book X. While I addressed this shortcoming above, the task now at hand is to broaden the themes proposed by Cavadini's analysis across Augustine's works in The Trinity and City of God. This task will be provisional in the sense that it is not exhaustive: yet it begins a worthwhile process of synthesizing Augustine's reflections regarding sacrifice, mediation, and the Eucharist over the course of his life and works.

Cavadini argues that the Eucharist exists in Augustine's Confessions "at the intersection of memory and hope." ${ }^{68}$ He continues, "It is the sacrament of a whole economy of mercy that forms memory in hope." ${ }^{69}$ What began as remembering Monica at the altar in the Eucharistic feast grows in Augustine's later works. The sacrifice of Christ, from which the Eucharist derives, is, indeed, offered by priests in the present time. Yet, Augustine explicitly recalls the

\footnotetext{
${ }_{68}^{68}$ John Cavadini, "Eucharistic Exegesis," 89.

${ }^{69}$ Ibid.
} 
memory of the "just and holy" Son of God, the root of all salvation history in The Trinity. ${ }^{70}$ Augustine roots the nexus of the worthiness of the Christian sacrifice in the actual incarnation, death, and resurrection of Christ. He offers an even deeper understanding of this process of memory and hope in City of God X.20 by linking the previous sacrifices of believers with the sacrifice of Christ. In other words, the Eucharist is the manifestation of the sacrifice of Christ that stretches through all salvation history, creating beneficiaries of Christ's sacrifice through all time. $^{71}$

One may also find the "Trinitarian mindfulness" described by Cavadini as originating in the Confessions when Christians reach mindfulness of the in-breaking of The Trinity through the Eucharist. $^{72}$ This insight also appears in The Trinity and the City of God. For instance, Augustine intimates that the beginning of understanding the oneness of the Father and the Son may only precede from a participation in Christ's body - that is to say, the Eucharistic body. ${ }^{73}$ This is the mediation that both mirrors and makes us participants in the oneness of God. Likewise, City of God suggests that we may only learn that which God desires for us through making our own selves a sacrifice: this sacrifice, of course, bases itself on the all-encompassing sacrifice of Christ. $^{74}$

Cavadini suggests that the Eucharist exists as the "sacrament of truth" because it claims "there is no God behind, beyond or above the mercy that is mediated in the sacrament of our redemption and encountered in the mutual bonds of charity."75 This may be coupled his description of the "ascent to mercy" whereby the Christian goes to the altar and is there met by

\footnotetext{
${ }^{70}$ Augustine, The Trinity, IV, iii, 19.

${ }^{71}$ Augustine, City of God, X.20.

72 John Cavadini, "Eucharistic Exegesis," 93.

${ }_{73}$ Augustine, The Trinity, IV, ii, 8.

${ }^{74}$ Augustine, City of God, X.6.

75 John Cavadini, "Eucharistic Exegesis," 95; 96-7.
} 
an outpouring of mercy that originates in God. ${ }^{76}$ These notions are further developed by the conclusion of Book X of the Confessions, as well as in The Trinity and City of God. Augustine describes his priesthood as a participation in the redemption in Christ; at the same time, the reality that he is a "poor man" does not negate his ability to preside at the altar so that others may "feast." ${ }^{77}$ Indeed, the charitable outpouring of the altar is gratuitous, but requires the true sacrifice re-presented for the entire Body of Christ to share. Likewise, God offers creation the gift of mercy in the sacrifice of Christ because there exists "a bridge to his [God's] eternity.",78 City of God continues this development, noting that the Christian "body" exists under the head of Christ, whereby it participates in Chris's true sacrifice and thus receives God's mercy. ${ }^{79}$

This expansion of John Cavadini's "Eucharistic Exegesis" brings my investigation of Augustine's views on sacrifice, mediation, and the Eucharist to a close. While the comments contained herein are not exhaustive, they do provide a broad overview of how Augustine saw the links between the true sacrifice of Christ, his role of mediation between God and humanity, as well as the Eucharist's ability to both mediate the God/human and human/human relationship. In the final analysis, Augustine developed a doctrine of sacrifice that relied upon a deep, even mystical, understanding of Christ's sacrifice as the perfect act of compassion and worship. Christians, therefore, re-present this same prefect sacrifice whenever they call upon Christ the priest as members of his body at the altar.

\footnotetext{
${ }^{76}$ Ibid., 98 .

${ }_{78}^{77}$ Augustine, Confessions, X.70.

${ }_{78}^{78}$ Augustine, On The Trinity, IV, iv, 24.

${ }^{79}$ Augustine, City of God, X.6.
} 


\section{Works Cited}

Augustine. City of God, trans. Henry Bettenson, London: Penguin Books, 2003.

. Confessions. trans. Maria Bouldling. New York: Random House, 1997.

. The Trinity. trans. Edmund Hill. Hyde Park, NY: New City Press, 2010.

Bonner, Gerald. "The Doctrine of Sacrifice: Augustine and the Latin Patristic Tradition" in

Sacrifice and Redemption: Durham Essays in Theology. ed. S.W. Sykes. Cambridge, UK: Cambridge, University Press, 1991. 101-117.

Cavadini, John. "Eucharistic Exegesis in Augustine's Confessions," Augustinian Studies 41:1. (2010) 87-108.

Daley, Brian. “A Humble Mediator: The Distinctive Elements in Saint Augustine's Christology” in Word and Spirit 9 (1987): 100-117.

Robert Daly. "Sacrifice in Origen and Augustine" in Studia Patristica. ed. Elizabeth Livingstone.

(Leuvan: Peters Press, 1989).

Muller, Earl. "The Priesthood of Christ in Book IV of the De trinitate" in Augustine: Presbyter

Factus Sum. ed. Joseph Linehard. New York, NY: Peter Lang, 1993. 135-149.

O’Grady, John. "Priesthood and Sacrifice in the City of God." Augustinia. 21 (1971): 27-44. 